\title{
Ounselle
}

\section{Bimbingan orang tua terhadap pasangan yang menikah di usia dini di Desa Keretak Kecamatan Sungai Selan Kabupaten Bangka Tengah Provinsi Kepulauan Bangka Belitung}

\section{Musdalifah'}

${ }^{1}$ Dosen Prodi BKI IAIN Syaikh Abdurrahaman Siddik Bangka Belitung

Korespondensi

musdalifaho896@gmail.com

\begin{abstract}
This research is motivated by the promiscuity of teenagers which results in frequent truancy, dropping out of school, getting pregnant out of wedlock. This results in marriage at an early age, even though physically and psychologically they are not ready so that parental guidance is needed for couples who marry at an early age. The purpose of this study was to find out the guidance for married couples who had been married at an early age in the village of Keretak Central Bangka, as well as to find out the factors that influence the guidance for the couple. This research is descriptive qualitative. Data was collected using unstructured interview techniques, observation, and documentation. The data that has been collected is then analyzed using the Miles and Huberman model. The results showed that guidance for couples who married at an early age turned out to be one solution for the development and increase in activities in the family. Likewise, couples who marry at an early age are able to maintain harmonious domestic relations.
\end{abstract}

KEYWORDS:

Parental guidance, early marriage. 


\title{
Ounselle
}

Reviewed : 14-Dec-2021 | Accepted : 21-Dec-2021 | Published : 31-Dec-2021

e-ISSN 2798-4230

DOI: 10.32923/couns.v1i2.2097 $\mathrm{p}-$ ISSN $x \mathrm{xxx}-\mathrm{x} x \mathrm{xx}$

\begin{abstract}
Abstrak
Penelitian ini dilatar belakangi oleh pergaulan bebas remaja yang mengakibatkan sering membolos, droup out dari sekolah, hamil di luar nikah. Hal tersebut mengakibatkan adanya pernikahan di usia dini, padahal secara fisik dan psikologi belum siap sehingga perlu adanya bimbingan orangtua terhadap pasangan yang menikah di usia dini. Tujuan penelitian ini di antaranya untuk mengetahui bimbingan terhadap pasangan suami istri yang pernah menikah di usia dini di desa Keretak Kabupaten Bangka Tengah, serta untuk mengetahui faktor yang mempengaruhi bimbingan bagi pasangan tersebut. Penelitian ini adalah deskriptif kualitatif. Pengumpulan data dilakukan dengan teknik wawancara tidak terstruktur, observasi, dan dokumentasi. Data yang telah dikumpul lalu dianalisis dengan model Miles dan Huberman. Hasil penelitian menunjukkan bahwa bimbingan terhadap pasangan yang menikah di usia dini ternyata mampu menjadi salah satu solusi bagi pengembangan dan peningkatan aktivitas di dalam keluarga. Begitu juga pasangan yang menikah di usia dini mampu mempertahankan hubungan rumah tangga yang harmonis. KATA KUNCI:

bimbingan orang tua, pernikahan usia dini.
\end{abstract}




\section{1 | Pendahuluan}

Pernikahan menurut Islam, dibangun atas dasar keinginan dan jujur serta dibina melalui tahapantahapan, yakni lamaran, akad nikah, dan pesta pernikahan. Memelihara kehormatan dan keturunan yang baik adalah puncak pemikiran manusia yang beradab dan kesempurnaan petujuk ilahi menyangkut relasi antara laki-laki dan perempuan [1].

Dengan perkawinan yang sah, pergaulan laki-laki dan perempuan terjadi secara hormat, sesuai kedudukan manusia. Adapun tujuan dari pernikahan yang sah adalah untuk memperoleh suasana kehidupan yang penuh ketenangan (sakinah), kehidupan yang penuh cinta (mawaddah), dan kehidupan yang penuh rasa kasih dan sayang (rahmah) [2].

Kehidupan keluarga bukan tentang cara untuk mendapat kebahagiaan individu semata, melainkan cara hidup bersama untuk menggapai kehidupan. Dengan demikian, usaha membangun rumah tangga yang bahagia akan berhasil apabila pasangan suami istri saling bertanggung jawab dalam kehidupan rumah tangga mereka.

Rumah tangga merupakan penyatuan kehidupan dua insan yang berbeda jenis, yakni laki-laki dan perempuan yang memiliki tugas dan tanggung jawab yang berbeda. Namun, dari sekian banyak tugas yang dititipkan kepada mereka, hanya ada satu tujuan yang hendak dicapai, yakni kebahagiaan lahir batin bersama pasangan [3].

Suami istri bersama-sama menjalankan tugas dan tanggung jawabnya masing-masing, sehingga terwujud ketentraman dan ketenangan hati sehingga sempurnalah kebahagiaan hidup berumah tangga. Dengan demikian, tujuan hidup berkeluarga akan terwujud sesuai dengan ajaran agama, karena dalam pernikahan ada beberapa hikmah, di antaranya: untuk mendapatkan keturunan untuk melanjutkan generasi yang akan datang [4]. Hal ini terlihat dalam QS An-Nisa: 1.

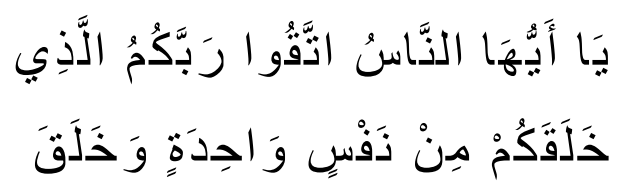




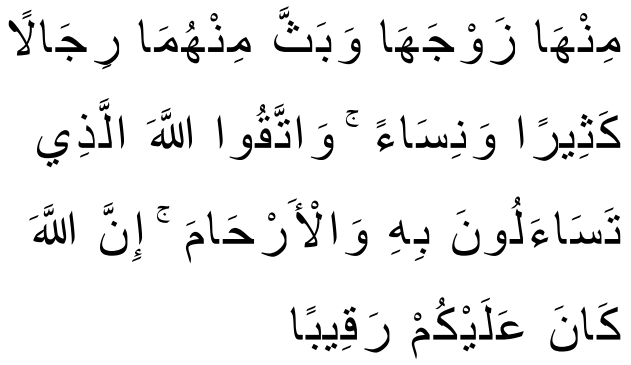

Artinya: "Wahai Manusia! Bertaqwalah kepada tuhanmu yang telah menciptakan kamu dari diri yang satu (Adam), dan (Allah) menciptakan pasangannya (Hawa) dari dirinya, dan dari keduanya Allah memperkembangbiakkan laki-laki dan perempuan yang banyak. Bertaqwalah kepada Allah yang dengan nama-Nya kamu saling meminta, dan (peliharalah) hubungan kekeluargaan. Sesungguhnya Allah selalu menjaga dan mengawasimu". (Q. S. An-Nisa' 1) [5].

\section{Bimbingan merupakan}

pemberian petunjuk atau tuntunan kepada orang lain yang membutuhkan [6]. Bimbingan dilakukan oleh setiap individu yang memiliki keunggulan tertentu untuk berjalan aktif diserahkan kepada yang dibimbingnya, pembimbing mengambil peranan secara aktif hanya dalam keadaan yang memaksa di dalam memberikan bimbingan. Tidak sesuai jika pembimbing membiarkan individu yang dibimbingnya terlantar keadaanya apabila ia telah nyata terlihat tidak dapat mengahadapi atau mengatasi persoalannya.

Bimbingan yang diberikan bertujuan untuk menghindari, mengatasi berbagai persoalan atau kesulitan yang dihadapi oleh individu di dalam kehidupannya, dan dapat mencapai kesejahteraan hidupnya, sesuai dengan petunjuk yang dikehendaki Allah SWT [7].

Dalam menjalani kehidupan, seseorang senantiasa memiliki berbagai permasalahan kehidupan, baik pribadi, kelompok sosial, akibat kebijakan-kebijakan politik negara. Berbagai permasalahan yang dihadapi dan yang terjadi di masyarakat, di antaranya psikologi, pendidikan, pekerjaan, kesulitan ekonomi, dan pernikahan dini, seolah-olah pernikahan yang dianggap sakral sekarang tidak ada lagi kesakralannya dianggap sementara.

Rumitnya permasalahan kehidupan diantaranya menyangkut masalah psikis membutuhkan jawaban yang tepat. Hal ini perlu nasihat yang baik dan tepat dalam menghadapi individu yang bimbing agar mereka 
kembali menemukan religious insight (wawasan religious), sehingga anak bimbing dapat kembali termotivasi dalam menjalankan kehidupan ini. Diantara permasalahan kehidupan individu pergaulan bebas remaja.

Pergaulan bebas remaja disebabkan oleh pelampiasan atas keinginan-keinginan yang tidak terpenuhi oleh orang tua dan juga kelalaian orang tua dalam mengawasi aktivitas-aktivitas anak. Akibatnya anak-anak mereka sering membolos, drop out dari sekolah, atau hamil di luar nikah. Hal tersebut yang kemudian menimbulkan adanya pernikahan di usia dini, yang secara psikologi belum siap menerima keadaan-keadaan yang ada dalam rumah tangga misalnya dalam mencari nafkah buat istri dan anak. Kondisi tersebut tidak terlepas dari fakta bahwa pada masa kini, remaja masih ingin-inginnya bermain, jalan-jalan, dan kumpul bersama teman-teman.

Dalam kondisi tersebut mereka belum bisa menerima tanggung jawab sebagai seorang ayah ataupun ibu ketika sudah memiliki anak. Adapun, tidak jarang keluarga yang melaksanakan pernikahan dini juga mampu mempertahankan hubungan antara suami, istri dan anak. Maka dari itu, perlu adanya bimbingan orang tua, seperti yang disampaikan oleh salah satu tokoh masyarakat, Bapak Muhari, Desa Keretak Kec. Sungai Selan Kab. Bangka Tengah [8].

Dalam segala aspek kehidupan rumah tangga harus diputuskan dan diselesaikan berdasarkan hasil musyawarah minimal antara suami istri karena mereka yang menjalani hubungan. Mereka yang lebih tahu dengan permasalahan yang sedang terjadi. Sehingga didapatkan cara mengatasi permasalahan di dalam kehidupan rumah tangga mereka.

Undang-Undang Nomor 1 Tahun 1974 tentang Perkawinan Pasal 6 ayat 2 menyatakan bahwa: untuk melangsungkan perkawinan, seseorang yang belum mencapai umur 21 tahun harus mendapatkan izin orang tua. Selanjutnya, Pasal 7 ayat 1 Undang-Undang Perkawinan menetapkan bahwa: Perkawinan hanya diizinkan jika pihak pria sudah mencapai umur 19 tahun dan pihak 
wanita sudah mencapai umur 16 tahun [9].

Dari permasalahan di atas, yang menjadi keinginan penulis untuk meneliti tentang bimbingan orang tua terhadap pasangan suami istri yang menikah di usia dini. Tujuannya adalah untuk melihat permasalahan dan dampaknya dalam bimbingan tersebut dapat meminimalisasi permasalahanpermasalahan yang terjadi.

\section{1 | Bimbingan Keluarga Sakinah yang dilakukan oleh Orang Tua}

$$
\text { Bimbingan Keluarga sakinah }
$$
terdiri dari kata bimbingan dan keluarga sakinah. Dalam bukunya Anas Salahudin, Bimbingan dan Konseling Prayitno dan Erman Amti mengemukakan bahwa bimbingan adalah proses pemberian bantuan yang dilakukan oleh orang yang ahli kepada seseorang atau kelompok, baik anak-anak, remaja, maupun dewasa [10]. Bimbingan dapat diberikan untuk menghindari kesulitan-kesulitan maupun untuk mengatasi persoalan-persoalan yang dihadapi oleh individu di dalam kehidupannya.

Bimbingan lebih bersifat pencegahan dari pada penyembuhan. Bimbingan yang dimaksudkan supaya individu atau sekumpulan individu dapat mencapai kesejahteraan hidup (life welfare) [11]. Bimbingan juga sebagai proses layanan yang diberikan kepada individu atau sekumpulan individu guna membantu mereka memperoleh pengetahuan dan keterampilan-keterampilan yang diperlukan dalam membuat pilihan, rencana, dan inteprestasi yang diperlukan untuk menyesuaikan diri yang baik [12].

Sedangkan keluarga sakinah adalah terdiri dari dua kata yaitu keluarga dan sakinah. Keluarga adalah masyarakat terkecil sekurangkurangnya terdiri dari suami isteri sebagai sumber intinya berikut anakanak yang lahir dari mereka. Adapun dalam bahasa Arab, kata sakinah di dalamnya terkandung arti tenang, terhormat, aman, penuh kasih sayang, dan memperoleh pembelaan. 
Keluarga sakinah adalah keluarga yang dibina atas perkawinan yang sah, mampu memenuhi hajat spiritual dan material secara layak dan seimbang, diliputi suasana kasih sayang antara anggota keluarga dan lingkungannya dengan selaras, serasi serta mampu mengamalkan, mengahayati dan memperdalam nilainilai keimanan, ketaqwaan dan akhlak mulia.

Salah satu pendekatan yang kini sering digunakan dalam kajian bimbingan keluarga adalah pendekatan teori sistem. Minuchin mengajukan skema konsep yang memandang keluarga sebagai sebuah sistem yang bekerja dalam konteks sosial yang memiliki tiga komponen. Pertama, struktur keluarga beberapa sistem sosiokultural yang terbuka dan transformasi. Kedua, keluarga senantiasa berkembang melalui sejumlah tahap yang mensyaratkan perstrukturan. Ketiga, keluarga beradaptasi dengan perubahan situasi kondisi dalam usahanya untuk mempertahankan kontinuitas dan meningkatkan pertumbuhan psikososial tiap anggotanya [13].

\section{2 | Unsur-unsur Bimbingan Keluarga Sakinah}

\section{a. Memilih calon yang baik}

Istri adalah tempat berteduh bagi suami dan sebagai teman hidup, mengatur rumah tangga, sebagai ibu anak-anak, tempat penyampaian isi hati. Maka suatu keharusan bagi kaum lelaki jika sudah ingin mempunyai istri hendaklah memilih istri yang baik, karena istri yang baik akan mendatangkan kebahagiaan dan ketentraman hidup dalam keluarga [14].

Dalam hal memilih istri yang baik Rasulallah saw memberikan suatu gambaran, bahwa ada empat faktor yang bisa dijadikan bahan pertimbangan dalam memilih pasangan. Diantaranya adalah karena harta bendanya, keturunannya, kecantikannya, dan agamanya [15].

"Nasehat Rasulallah saw tidak berarti seseorang laki-laki harus kawin dengan wanita beragama sekalipun tidak cantik, tetapi kecantikan, kekayaan, dan keturunan boleh dijadikan dasar untuk mencari wanita yang akan dinikahinya asalkan beragama dan dia benar-benar shalelah. Sebab wanita yang baik bagi seseorang laki-laki adalah wanita yang 
menyenangkan bila dipandang. Sebagaimana sabda Rasulallah saw, yang artinya: "sebaik-baik wanita adalah yang apabila kamu memandang kamu akan senang, apabila kamu perintah ia patuh kepadamu, apabila kamu beri sebagian ia akan menerimanya, apabila kamu pergi ia akan menjaga dirinya dan menjaga hartamu." (HR. Nasa'i, dan lain-lain).

Maksud cantik didalam hadits diatas adalah cantik menurut padangan seseorang, bukan cantik menurut pandangan seseorang, bukan cantik menurut pandangan umum, sebab kecantikan seseorang itu punya banyak penilaian, seseorang mengatakan cantik mungkin yang lain tidak begitupun sebaliknya.

Jika seseorang orang laki-laki disuruh untuk berhati-hati dalam memilih calon istri, maka seseorang wali juga berhati-hati dalam mencari jodoh anak wanitanya, dengan kehormatan dan kemuliaannya. Hendaklah seorang wali tidak mencari menantu orang yang tidak beragama, tidak berakhlak. Sebab orang yang baik orang yang beragama dan berakhlak akan mempergauli istrinya atau akan melepaskannya dengan baik pula.

\section{b. Mewujudkan harmonisasi}

\section{hubungan suami istri}

Pertama, adanya saling pengertian, diantara suami istri hendaknya saling memahami dan mengerti tentang keadaan masingmasing baik secara fisik maupun secara mental. Perlu diketahui bahwa suami istri sebagai manusia masingmasing memiliki kelebihan dan kekurangannya. Masing-masing sebelumnya tidak saling mengenal, bertemu setelah sama-sama dewasa tidak saja berbeda jenis tetapi masingmasing memiliki perbedaan sikap, tingkah laku dan perbedaan pandangan hidup.

Kedua, saling menerima kenyataan setiap pasangan suami isteri harusnya menyadari bahwa jodoh, rezeki, maut ada pada kekuasaan Allah SWT, tidak dapat dirumuskan secara matematis, namun tugas kita sebagai manusia ialah berusaha, berdoa dan ikhtiar. Hasilnya barulah merupakan suatu kenyataan yang harus kita terima dalam keadaan apapun, termasuk keadaan suami istri 
masing-masing kita terima dengan tulus dan ikhlas.

Ketiga, saling menyesuaikan diri, penyesuaian diri dalam keluarga berarti setiap anggota keluarga berusaha untuk saling mengisi kekurangan pada diri masing-masing serta mau menerima dan mengakui kelebihan yang ada pada diri masingmasing dalam lingkungan keluarga. Kemanapun penyesuaian diri oleh masing-masing anggota keluarga mempunyai dampak yang positif baik pembinaan keluarga maupun masyarakat dan bangsa [16].

Keempat, memupuk rasa cinta, setiap pasangan suami istri menginginkan hidup bahagia, kebahagiaan hidup adalah relative sesuai dengan cita rasa dan keperluan masing-masing rumah tangga. Namun begitu setiap orang berpendapat sama bahwa kebahagiaan adalah segala sesuatu yang dapat mendatangkan ketentraman, keamanan dan kedamaian serta segala sesuatu yang bersifat pemenuhan keperluan mental spiritual manusia. Untuk dapat mencapai kebahagiaan keluarga hendaknya antara suami isteri senantiasa berupaya memupuk rasa cinta dengan rasa saling menyayangi, kasih mengasihi, hormat menghormati serta saling harga menghargai dengan penuh keterbukaan.

Kelima, melakukan musyawarah, dalam hal ini dituntut sikap terbuka, lapang dada, jujur, mau menerima dan memberi serta sikap tidak mau menang sendiri dari pihak suami maupun istri. Sikap suka musyawarah dalam keluarga dapat menumbuhkan rasa memiliki dan rasa tanggung jawab diantara para anggota keluarga dalam menyelesaikan dan memecahkan masalah-masalah yang timbul. Keenam, Suka memaafkan, diantara suami isteri harus ada sikap kesediaan untuk saling memaafkan atas kesalahan masing-masing. hal ini penting karena tidak jarang persoalan yang kecil dan sepeleh dapat menjadi sebab terganggunya hubungan suami istri yang tidak jarang dapat menjurus kepada perselisihan yang berkepanjangan. Ketujuh, berperan serta untuk kemajuan bersama, masing-masing suami istri harus berusaha saling membantu pada 
setiap usaha untuk peningkatan dan kemajuan bersama yang pada gilirannya menjadi kebahagiaan keluarga.

\section{c. Menciptakan hubungan antara anggota keluarga dan lingkungan}

Pertama, hubungan antara anggota keluarga, hubungan persaudaraan yang lebih luas menjadi ciri dari masyarakat kita. Hubungan antara sesama keluarga besar harus terjalin dengan baik antara kedua belah pihak.suami harus baik dengan pihak keluarga istri begitu juga istri harus baik dengan pihak keluarga suami.

Kedua, hubungan dengan tetangga dan masyarakat. Tetangga adalah orang-orang terdekat yang umunya merekalah orang-orang yang pertama tahu dan dimintai pertolongan. Saling kunjung mengunjungi dan saling mengirimi adalah suatu perbuatan terpuji itu akan menimbulkan kasih sayang antara satu dengan lainnya. Begitu penting hubungan baik dengan semua pihak, karena pada dasarnya manusia itu saling membutuhkan dan kebutuhan-kebutuhan.

\section{3 | Faktor-Faktor yang Mempengaruhi Bimbingan Orang Tua Terhadap Pasangan yang Menikah di Usia Dini.}

\section{Faktor internal}

Pertama, masalah ekonomi. Keadaan ekonomi keluarga yang serba kekurangan dalam memenuhi kebutuhan-kebutuhan terhadap kepentingan rumah tangga. Hal ini tentunya berpengaruh kepada perasaan orang tua terhadap kebutuhan anaknya [17]. Jika orang tua yang terlalu sibuk dalam mementingkan pekerjaan dari pagi hingga larut malam, tidak bisa memberikan perhatian yang cukup kepada anak-anaknya. Sewaktu dirinya kembali ke rumah, anak-anaknya telah tertidur atau akan tidur, dan ia dalam keadaan lelah kehilangan tenaga, sehingga perlu makan, lalu tidur dan istirahat. Ini pun bila ia tidak menyibukkan dirinya di rumah dengan catatan-catatan pekerjaannya [18].

Kedua, Rasa Bosan, Rasa bosan sering kali hinggap dalam kehidupan 
rumah tangga, dan hal ini sangat wajar dan tidak bisa dihindari. Setinggi apa pun prestasi, kebaikan, atau keistimewaan, selama masih ada di dunia. Pasti memiliki kelemahan dan kekurangan. Seistimewa apa pun pasangan hidup seseorang, pasti memiliki kekurangan. Sering kali tidak disadari masing-masing pasangan. Misalnya, bosan dengan keadaan rumah, jemu terhadap penampilan pasangan, kesal terhadap anak-anak, atau jenuh menghadapi segala permasalahan rumah tangga.

Ketiga, berkata kasar, suami dan istri harus bisa mengendalikan emosi. Saat suasana apa pun, baik muncul masalah ataupun tidak, seyogyanya kata-kata kasar tidak terucap. Dalam kehidupan rumah tangga, hal-hal yang harus dimiliki setiap pasangan adalah rasa saling menghormati, menghargai, berkomunikasi, dan berinteraksi dengan cara yang baik [19]. Keempat, pendidikan, ditinjau dari sudut pendidikan, maka yang perlu diperhatikan adalah bagaimana terjadinya perbedaan-perbedaan itu dan bagaimana cara melakukan pengubahan pada diri individu, sebab itu pendidikan itu proses sosial pembentukan corak diri individu. Ada dua prinsip yang terpakai dalam usaha dalam usaha memahami gejala ini. Yaitu, prinsip interaksi dan prinsip intensitas frekuensi.

Kelima, adat istiadat, faktor yang paling tinggi frekuensi dan intensitasnya pada awal masa awal dari proses pembentukan corak diri adalah adat istiadat yang terdapat di dalam keluarga. Hal ini dinyatakan oleh Rasul: "setiap anak dilahirkan dalam keadaan bersih, polos, lalu orang tuanyalah yang mengyahudikan atau menasranikan atau memajusikannya”. Jika adat kebiasaan itu salah dan jahat, maka corak diri individu yang dibesarkan di dalam adat istiadat itu menjadi jahat pula.

\section{Faktor Eksternal}

Lingkungan masyarakat adalah situasi atau kondisi interaksi sosial dan sosiokultural yang secara potensial berpengaruh terhadap perkembangan fitrah beragama atau kesadaran beragama individu terutama anakanak atau remaja akan melakukan interaksi sosial dengan teman 
sebayanya atau anggota masyarakat lainnya. Apabila teman sepergaulan itu menampilkan perilaku yang sesuai dengan nilai-nilai agama berakhlak baik, maka anak remaja pun cenderung akan berakhlak baik.

Menurut Hurlock, mengemukakan bahwa standar atau aturan-aturan kelompok bermain memberikan pengaruh kepada pandangan moral dan tingkah laku para anggotanya. Corak perilaku anak atau remaja merupakan cerminan dari perilaku warga masyarakat pada umumnya. Oleh karena itu, di sini dapat dikemukakan bahwa kualitas perkembangan kesadaran beragama bagi anak sangat bergantung pada kualitas perilaku atau pribadi orang dewasa atau warga masyaraka [20].

\subsection{Komunikasi yang Baik untuk Menciptakan Keluarga Sakinah}

Komunikasi keluarga berkontribusi bagi pembentukan konsep diri, salah satu sama lain ialah "berbicara" meliputi unsur-unsur komunikasi verbal dan non verbal dengan cara-cara yang akan berkontribusi bagi pengembangan konsep diri yang kuat bagi semua anggota keluarga terutama anak-anak muda.

Komunikasi keluarga memberikan pengakuan dan dukungan yang diperlukan Tanggung jawab kedua dari para anggota keluarga ialah berinteraksi terhadap satu sama lain dengan cara-cara mengakui dan mendukung para sanak secara individual. Pengakuan dan dukungan membantu para anggota keluarga merasa diri mereka berarti dan membantu diri mereka mengatasi pada masa-masa sulit di mana kita semua yang harus menghadapinya.

\section{2 | Metode}

Adapun jenis penelitian yang digunakan peneliti adalah jenis penelitian deskriptif kualitatif. data deskriptif berupa kata-kata tertulis atau lisan dari orang-orang dan perilaku yang dapat di amati [21]. Adapun untuk sumber data dalam penelitian ini terbagi dalam dua bagian, yaitu: pertama, sumber data primer yang diperoleh langsung dari sumber data utama di lokasi 
penelitian. Data ini diperoleh secara

langsung baik yang dilakukan melalui wawancara, observasi dan dokumentasi. Sumber ini peneliti mengambil dari wawancara pasangan suami istri, dan orang tua. Kedua, data sekunder merupakan bentuk data pelengkap dalam penelitian ini. Seperti, tokoh agama, tokoh masyarakat, dokumen, dan buku.

Untuk mendapatkan data penelitian, maka peneliti menggunakan teknik pengumpulan data sebagai berikut:

\section{a. Wawancara}

Dalam hal ini peneliti menggunakan wawancara tidak terstruktur [22]. Untuk menemukan informasi yang bukan baku dan menekankan pada penyimpangan dan perlu penafsiran yang tidak lazim dan dilakukan kebebasan untuk bertanya.

Dalam tahapan wawancara ini, peneliti melakukan wawancara dengan beberapa pasangan suami istri dan orang tua dari pasangan tersebut. Wawancara digambarkan dalam tabel berikut:

\section{Tabel I.I Instrumen Wawancara}

\begin{tabular}{|c|c|c|c|}
\hline No & Dimensi & Indikator & Informan \\
\hline 1. & $\begin{array}{l}\text { Bimbingan orang } \\
\text { tua terhadap } \\
\text { pasangan yang } \\
\text { menikah di usia dini } \\
\text { (Menurut Karim } \\
\text { Asy-Syadzily dalam } \\
\text { bukunya Bekal } \\
\text { Menuju Keluarga } \\
\text { Sakinah. Hal. 36) } \\
\text { dan (Menurut Umi } \\
\text { Hasunah Ar-Razi } \\
\text { dalam bukunya } \\
\text { Disayang Suami } \\
\text { Hingga Di Surga. } \\
\text { Hal. 177-208) }\end{array}$ & $\begin{array}{l}\text {-Memberikan } \\
\text { motivasi kepada } \\
\text { pasangan. } \\
\text {-Meningkatkan } \\
\text { komunikasi } \\
\text { pasangan. } \\
\text {-Meningatkan } \\
\text { spiritual } \\
\text { pasangan. } \\
\text {-Membangun } \\
\text { harmonisasi } \\
\text { pasangan. }\end{array}$ & $\begin{array}{l}\text {-Orang Tua } \\
\text {-Pasangan }\end{array}$ \\
\hline 2. & 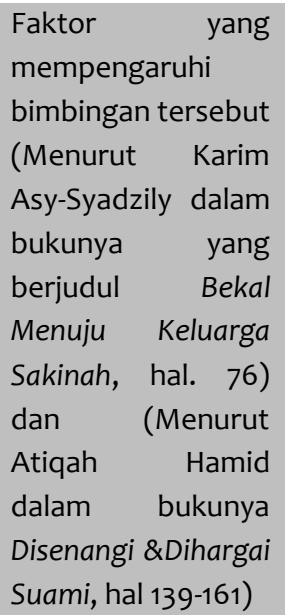 & $\begin{array}{l}\text { Faktor Internal } \\
\text { masalah } \\
\text { ekonomi } \\
\text { rasa bosan } \\
\text { berkata kasar } \\
\text {-pendidikan } \\
\text {-adat istiadat } \\
\text { Faktor Eksternal } \\
\text {-lingkungan } \\
\text { masyarakat }\end{array}$ & $\begin{array}{l}\text { Orang tua } \\
\text { Pasangan } \\
\text { Tokoh } \\
\text { masyarakat } \\
\text { Tokoh agama }\end{array}$ \\
\hline
\end{tabular}

\section{b. Observasi}

Observasi adalah kegiatan yang dilakukan dengan pancaindra mata yang dilengakapi dengan telinga, mulut, penciuman, dan kulit [23]. Pengamatan langsung kepada suatu objek yang akan diteliti. Observasi dapat dilakukan dalam suatu waktu yang singkat [24]. Untuk memperoleh informasi atau data sebagai tujuan 


\section{Ounselle}

Reviewed : 14-Dec-2021 | Accepted : 21-Dec-2021 | Published : 31-Dec-2021

penelitian.[25] Metode ini digunakan untuk mengamati secara langsung kegiatan bimbingan orang tua terhadap pasangan yang menikah di usia dini. Bentuk observasi tersebut dapat digambarkan dalam tabel sebagai berikut:

\section{Tabel 1.2 Instrumen Observasi}

\begin{tabular}{|c|c|c|c|}
\hline No & $\begin{array}{c}\text { Jenis } \\
\text { Dokumentasi }\end{array}$ & Data & Sumber \\
\hline 1. & Formal & $\begin{array}{l}\text { - Daftar } \\
\text { agama, } \\
\text { sosial, dan } \\
\text { budaya } \\
\text { - Daftar } \\
\text { penduduk } \\
\text { - Daftar } \\
\text { pernikahan } \\
\text { - Daftar } \\
\text { perceraian } \\
\text { - Daftar } \\
\text { rujuk }\end{array}$ & $\begin{array}{l}\text { Kantor } \\
\text { Desa } \\
\text { Keretak } \\
\text { dan KUA } \\
\text { Sungai } \\
\text { Selan }\end{array}$ \\
\hline 2. & Personal & $\begin{array}{l}\text { - Foto nikah } \\
\text { - Buku nikah }\end{array}$ & Pasangan \\
\hline
\end{tabular}

c. Dokumentasi

Dokumentasi adalah setiap

bahan tertulis ataupun film.

Dokumentasi, yakni teknik pengumpulan data dengan menjadikan dokumen-dokumen sebagai sumber data [26]. (Gambar, tulisan, suara dan lain-lain) terhadap segala hal baik objek atau juga peristiwa yang terjadi. Adapun yang diperoleh dari dokumentasi ini adalah kegiatan bimbingan yang dilakukan orang tua kepada pasangan suami istri. Data terkait seperti yang digambarkan dalam tabel berikut:

Tabel 1.3 Instrumen Dokumentasi

\begin{tabular}{|c|c|c|}
\hline No & Aktivitas & Keterangan \\
\hline 1. & $\begin{array}{l}\text { Interaksi } \\
\text { orang tua } \\
\text { dengan } \\
\text { pasangan }\end{array}$ & $\begin{array}{ll}\text { - } & \text { Komunikasi } \\
\text { - } & \text { Tempat } \\
\text { - } & \text { Waktu }\end{array}$ \\
\hline 2. & $\begin{array}{l}\text { Interaksi } \\
\text { dengan } \\
\text { lingkungan } \\
\text { masyarakat }\end{array}$ & $\begin{array}{l}\text { Memberikan dampak yang } \\
\text { baik dan juga buruk. }\end{array}$ \\
\hline 3. & $\begin{array}{l}\text { Interaksi } \\
\text { pasangan } \\
\text { (suami dan } \\
\text { istri) }\end{array}$ & $\begin{array}{l}\text { Perubahan perilaku setelah } \\
\text { perkawinan berlangsung. }\end{array}$ \\
\hline 3 & \multicolumn{2}{|c|}{ | Hasil dan Pembahasan } \\
\hline 3.1 & \multicolumn{2}{|c|}{ | Kegiatan Bimbingan Orang } \\
\hline & \multicolumn{2}{|c|}{ Tua Terhadap Pasangan yang } \\
\hline & \multicolumn{2}{|c|}{ Menikah di Usia Dini di Desa } \\
\hline & Keretal & \\
\hline & Adapu & kegiatan bimbingan \\
\hline
\end{tabular}

yang dilakukan oleh orang tua kepada pasangan yang menikah di usia dini diantanya sebagai berikut:

\section{Memberikan motivasi kepada pasangan}

Dalam hal tersebut orang tua maupun pasangan berupaya mempertahankan hubungan rumah tangga sakinah, mawaddah, 
warahmah. Dengan berbagai permasalahan yang mereka hadapi Cara yang dilakukan dalam mengatasi masalah dalam keluarga oleh orang tua dan pasangan itu sendiri adalah berdiskusi dengan pasangan yang berselisih, agar terhindar dari perceraian.

Maka dari itu sangatlah penting bagi mereka yang sudah mempunyai keluarga untuk saling memberikan motivasi, seperti yang dikatakan oleh pasangan Redi Wahyudi dan Risqi ketika dalam keadaan yang tidak diinginkan mereka saling memberikan semangat serta dukungan agar tetap kuat dalam menghadapi permaslahan, tetap tegar dalam mengatasi suatu ketidak nyamanan dalam rumah tangga [27].

Pihak orang tua hanya menyarankan kepada pasangan suami istri untuk terlebih dahulu diselesaikan secara kekeluargaan yaitu meminta pendapat kepada keluarga. Orang tua hanya berharap supaya pasangan tersebut dapat didamaikan dan terhindar dari perceraian. Hal tersebut juga dikatakan oleh Sukarmila bahwa jika sudah menikah itu mempunyai tanggung jawab lebih, terus bekerja mencari nafkah karena sudah mempunyai istri dan anak yang dihidupi [28].

\section{Meningkatkan}

\section{Komunikasi}

\section{Pasangan}

Bimbingan kepada pasangan suami isteri, hal pertama yang harus mereka ketahui adalah tugas dan tanggung jawab masing-masing. tidak diberatkan kepada suami dan tidak diberatan kepada isteri pula harus sama-sama memikul tanggung jawab tersebut. Itu lah yang membuat pasangan suami istri tidak mudah untuk bercerai. Sebagai orang tua yang mempunyai tugas dan tanggung jawab terhadap keluarga, khususnya anak, harus lebih aktif dalam memberikan bimbingan kepada anakanaknya. Hal ini dikemukakan oleh Bapak Mohari, bimbingan yang diberikan orangtua kepada anaknya yang menikah di usia dini adalah hal yang wajib karena anak-anak mereka yang menikah itu belum siap secara psikologi maupun secara fisik. Maka jika tidak diberikan dibimbingan 
dtakutkan akan terjadi hal-hal yang tidak diinginkan [29].

Hubungan antara suami dan istri yang baik tentu dengan komunikasi yang baik pula untu menciptakan keluarga yang harmonis. Menurut Rendi Alamsyah, berkomunikasi dengan baik antara suami, isteri dan anak sangatlah penting ketika ingin menyampaikan suatu pesan ataupun dalam berkata, untuk mempertemukan apa yang diinginkan satu dengan lainnya. Dengan seperti itu tidak ada salah paham di antara suami, isteri dan anak [30].

\section{Meningkatkan Spiritual Pasangan}

Ibadah adalah obat bagi setiap problem yang dihadapi. Begitupun ketika ada permasalalan dalam rumah tangga ataupun pada diri sendiri ketika tidak merasa nyaman dengan suatu keadaan. Ibadah merupakan suatu kewajiban bagi setiap muslim. Selain itu, apa pun yang telah diajarkan agama tentang berbagai macam hal seperti cara berpakaian seseorang agar menutup auratnya. Dalam hal ini, Yati menyampaikan kepada anak- anaknya untuk berpakaian yang sopan, menjaga aurat, sholat lima waktu jangan ditinggalkan karena itu yang menjaga kita dari hal-hal yang tidak diinginkan [31].

Hal tersebut dirasakan oleh Rizqi, yang selalu mengajak suaminya untuk sholat ketika sudah masuk waktunya. Menurutnya seorang istri harus selalu memperhatikan suami dan anak-anaknya dengan baik, karena wanita yang di dunianya solehah akan menjadi cahaya bagi keluarga, akan melahirkan keturunan yang baik. Sedangkan seorang suami harus menjadi pemimpin dalam keluarga dan melaksanakan segala kewajiban walaupun terkadang belum dilaksanakan semua [32].

\section{Membangun}

Harmonisasi

\section{Pasangan}

Kehidupan rumah tangga yang harmonis dan bahagia tentu impian setiap pasangan. Dalam hal tersebut setiap pasangan harus sama-sama menjaga keutuhan rumah tangga dengan mengenal karakter masingmasing pasangan, dan saling menghormati. 
Dalam hal ini, Holiyapan, mengaku bahwa ketika berhadapan dengan pasangan yang berbeda pendapat, karakter, sifat. harus tetap menerima dengan baik walaupun dengan berat hati ketika memang harus untuk diterima. Dan ketika ada masalah atau hal yang tidak diinginkan mereka hanya terdiam selsesai-selesai disitu tidak dipanjang lebarkan [33].

Berdasarkan hasil wawancara tersebut adalah, adanya beberapa orang tua yang selalu memberikan nasihat untuk anak-anaknya agar tetap menjaga keharmonisan rumah tangga. Dan pasangan yang diberikan nasihat tersebut menerima dengan baik, karena itu sangat membantu untuk selalu memberikan dorongan yang positif. walaupun ada beberapa pasangan yang tidak mendengarkan. Beberapa pasangan juga ada yang tidak terlalu bergantung kepada orang tua dalam hal apapun. Setelah menikah mereka sudah mempunyai rumah sendiri.

\section{2 | Faktor yang Mempengaruhi Pelaksanaan Bimbingan}

\section{Terhadap Pasangan yang Menikah di Usia Dini}

\section{Faktor Eksternal}

Lingkungan masyarakat memberi pengaruh yang sangat signifikan terhadap keberhasilan bimbingan orang tua terhadap pasangan yang menikah di usia dini. Menurut Junata, lingkungan masyarakat mendukung adanya bimbingan orang tua terhadap pasangan yang menikah di usia dini, membantu para pasangan dalam memberikan nasihat pernikahan kepada anak-anaknya. Lingkungan masyarakat sangat berpengaruh terhadap proses bimbingan tersebut [34].

Adapun faktor-faktor pendukung dan penghambat tentu memberikan dampak terhadap keberhasilan upaya-upaya yang dilakukan. Faktor-faktor yang muncul kepermukaan merupakan sarana untuk memahami serta menjelaskan apakah peran orangtua serta pasangan dalam memberikan bimbingan terhadap keluarga.

Menurut Holiyapan, pasangan yang menikah di usia dini mereka 
mengaku bahwa bimbingan yang di berikan orang tua sangat penting dan bermanfaat bagi mereka semua. Pasangan suami istri ini mengaku mendapatkan ilmu pengetahuan yang baru terkait dengan nasehat-nasehat yang disampaikan, karena sebelumnya mereka menyadari bahwa belum mengetahui apa-apa yang menjadi tugas dan tanggung jawab sebagai pasangan suami istri [35].

\section{Faktor Internal}

\section{a. Masalah Ekonomi}

Ekonomi merupakan masalah yang sering dihadapi pasangan. Problem yang tidak bisa disepelekan. Rata-rata rumah tangga dengan taraf ekonomi rendah, rentan mengalami banyak permasalahan dibandingkan dengan rumah tangga yang stabil atau lebih.

$$
\text { Dalam hal ini, Sukarmila }
$$

mengakui bahwa ekonomi menjadi hal penting dalam kehidupan rumah tangga karena dengan ekonomi stabil untuk memeberikan nafkah kepada keluarga, kebutuhan tercukupi. Walaupun uang bukan segalanya. Namun, dalam sebuah rumah tangga akan mengalami kesulitan dalam memenuhi kebutuhan jika tidak memiliki uang. Semua akan terbayar ketika setiap pasangan bekerja keras, berusaha dengan baik, saling mendukung dan saling mengingatkan. [36].

Rendi Alamsyah, juga mengatakan bahwa tidak berhenti bekerja demi memenuhi kebutuhan rumah tangga. Walaupun terkadang rezeki tidak selalu banyak, terkadang dapat banyak, terkadang juga kurang. Tapi ia tetap bekerja keras, sebagai seorang suami yang bertanggung jawab terhadap semua kebutuhan keluarga terutama istri dan anaknya [37].

\section{b. Rasa Bosan}

Rasa bosan seringkali hinggap dalam kehidupan rumah tangga, dan hal ini sangat wajar dan tidak bisa dihindari. Setinggi apa pun prestasi, kebaikan atau keistimewaan, selama masih ada di dunia, pasti memiliki kelemahan dan kekurangan. Hal ini sering kali tidak disadari oleh setiap masing-masing pasangan. Misalnya, bosan dengan keadaan rumah, jemu terhadap anak-anak, atau jenuh 
mengahadapi segala permasalahan

rumah tangga.

Hal ini dirasakan oleh Rendi Alamsyah, rasa bosan itu pasti ada yang namanya manusia setiap apa yang dilakukan atau yang diinginkan tidak selalu ada. Ketika itu dirasakan mereka hanya saling diam untuk meredam rasa bosan itu sampai kembali ke dalam keadaan nyaman [38].

Adapula Sidiq, pasangan yang berpendapat bahwa rasa bosan di dalam sebuah keluarga tidak bisa di pungkiri karena setiap individu masing-masing pasangan memiliki cara tersendiri dalam melakukan atau menyelesaikan hal-hal yang diinginkan ataupun tidak diinginkan. Misalnya, dalam memberikan cinta dan sayang kepada keluarga, mengurusi suami, istri dan anak, memasak, bekerja berkomunikasi dan lain-lain [39].

\section{c. Berkata Kasar}

Hidup berumah tangga tidak selalu seperti melintas dialan tol, ada saatnya senang, ada kalanya muncul perselisihan dan cara pandang yang berbeda mengenai satu hal dengan hal yang lain. Ketika cara pandang berbeda, timbul masalah, emosi kedua pasangan memuncak, sering kali rasa marah mengalahkan logika dan nurani. Kata-kata kasar pun mudah diucapkan. Berkata kasar, terutama kepada suami, merupakan suatu perbuatan yang tercela. Berkata kepada suami merupakan salah satu bentuk kefasikan, bahkan bukan termasuk karakter perempuan yang Islami. Karena itu, jagalah mulut agar tidak mudah mengeluarkan kata-kata kasar atau sesuatu yang tidak patut untuk diucapkan kepada suami. Begitu pula sebalinya suami kepada istri juga seperti itu. Karena harus menjaga perasaan satu dengan yang lainnya. Seperti dikatakan oleh Fazil, yang tidak pernah berkata kasar terhadap istri dan anaknya. Karena ketika ada permasalahan dalam rumah tangga ia selalu menghadapi dengan sabar dan tenang [40].

\section{d. Pendidikan}

Rendahnya pendidikan merupakan faktor terjadinya pernikahan usia dini. Para orang tua yang berpendidikan rendah merasa senang jika anaknya sudah ada yang menyukai, dan orang tua tidak 
mengetahui adanya akibat dari pernikahan dini ini. Pendidikan akan memberikan dampak pola piker dan pandangan orang tua terhadap mendidik anaknya. Semakin tinggi pendidikan yang di miliki oleh orang tua maka akan semakin memperluas dan melengkapi pola berpikirnya dalam mendidik anaknya.

Menurut Heri, pendidikan orang tua juga sangat berpengaruh terhadap pandangan terhadap peran dan posisinya anak dalam keluarga. Mereka sering beranggapan bahwa, wanita hanya akan menjadi istri dan bekerja di dapur dan jika menikah nanti akan ikut dengan suami. Hal ini mengakibatkan kesempatan untuk menempuh pendidikan bagi perempuan akan sangat kecil. Sehingga kecenderungan anak perempuan untuk nikah di usia muda semakin besar [41].

\section{e. Adat Istiadat}

Para individu tradisional menunjukkan faktor adat istiadat budaya yang dominan menjadi pembentukan corak diri individu. Ungkapan apa yang kami dapati pada orang tua kami, menunjukkan adanya adat istiadat atau budaya yang telah diinteraksikan secara intensif oleh orang tua kepada anaknya.

Orang tua dengan sengaja menghadapkan dan mengamalkan adat istiadat kepada anaknya dan anak aktif menserasasikan diri dengan apa yang dialami dan dipahami itu. Proses ini diperkuat oleh perasaan takut dari pihak anak kepada orang tuanya. Dengan demikian terdapat dua faktor yang dihadapi oleh anak yaitu adat istiadat dan orang tua yang membawakan adat istiadat itu itu, maka tertonjollah tingginya frekuensi dan intensitas adat istiadat yang dihadapi dan dialami oleh anak [42].

Apakah dengan terjadinya perubahan pada individu akan menimbulkan perubahan pada masyarakat ataukah untuk terjadinya perubahan pada individu harus terjadi dulu perubahan pada masyarakat. Para ahli ilmu masyarakat dan ahli budaya cenderung menonjolkan masyarakat dan budaya sehingga memandang individu itu hanya produk dari masyarakat atau budaya. 
Qunselle

Reviewed : 14-Dec-2021 | Accepted : 21-Dec-2021 | Published : 31-Dec-2021

Sebaliknya para ahli ilmu jiwa cenderung menonjolkan individu dan memandang individu dan memandang masyarakat sebagai produk dari individu.

\section{4 | Penutup}

Berdasarkan hasil penelitian tentang bimbingan orang tua terhadap pasangan yang menikah di usia dini, penulis dapat menarik kesimpulan, bahwa pelaksanaan bimbingan tersebut sudah berjalan dengan baik. Dalam pelaksanaan tersebut mampu meningkatkan aktivitas di dalam keluarga. Begitu juga bagi pasangan yang menikah di usia dini bisa mempertahankan hubungan rumah tangga yang harmonis.

Meskipun ada beberapa orang tua yang tidak menjalankan bimbingan tersebut melainkan pasangan itu sendiri yang menjalankan tugas dan tanggung jawabnya. Mengingat sangat penting bimbingan terhadap pasangan yang menikah di usia dini. Pihak orang tua dituntut untuk lebih memperhatikan aspek apa saja yang membuat bimbingan tersebut berjalan dengan baik. Sehingga mengahasilkan arahan yang tidak hanya bagi pasangan suami istri yang bermasalah dalam rumah tangganya akan tetapi seluruh lapisan masyarakat bisa merasakan manfaat dari bimbingan itu sendiri. 


\section{Daftar Pustaka}

[1] Ibrahim, I. Kekuatan Doa Istri Mengiringi Suami Memanapaki Liku-liku Kehidupan. Jakarta: PT. Gramedia. 2011; 9.

[2] Nasution, K. Islam Tentang Relasi Suami dan Istri. Yogjakarta: Academia \& Tazzafa, 2004; 35.

[3] Ar-Razi, HU. Disayang Suami Hingga di Surga. Yogjakarta: Diva Pres. 2015; 15.

[4] Tihami, SS. Fikih Munakahat. Jakarta: Rajawali Pres. 2014; 153.

[5] Departemen Agama RI. AlQur'an dan Terjemahan. Jakarta: Yayasan Penerjemahan dan Penafsiran Al-Qur'an, 2009; 77.

[6] Amin, MS. Bimbingan dan konseling Islam. Jakarta: Amzah. 2010; 3 .

[7] Departemen Agama RI Dirjen Bimbingan Agama Islam, (UU Nomor 1 Tahun 2013;89-90.

[8] Salahudin, A, Bimbingan dan Konseling, Bandung: CV Pustaka Setia. 2010; 14.

[9] Walgito, B, Bimbingan dan Konseling, Yogyakarta: C. V Andi Offset. 2004; 6-7.

[10] Prayitno. Dasar-dasar Bimbingan dan Konseling. Jakarta: PT Rineka Cipta. 2004; 94.

[11] Sri L, Psikologi Keluarga, Jakarta: Kencana, 2012; 26-27.
[12] Burhan S. Temukan Aku Dalam Istikharahmu, Solo: Samudera, 2013; 185.

[13] Mazhahiri. Pintar Mendidik Anak, Panduan Lengkap Bagi Orang Tua, Guru dan Masyarakat Berdasarkan Ajaran Islam. Jakarta: Lentera. 2002;26.

[14] Moleong, L. Metode Penelitian Kualitatif, Bandung: PT Remaja Rosdakarya. 2012; 4.

[15] Mulyono, D. Metodelogi Penelitian Kualitatif: Paradigma Baru Ilmu Komunikasi dan Ilmu Sosial Budaya, Bandung: Rosda. 2004;180.

[16] Zulkifli, Metode Penelitian Suatu Pengantar. Bangka Belitung: Siddik P. 2007;68.

[17] Nasution. S. Metode Research. Yogjakarta: Bumi Aksara. 1996;113.

[18] Rahman, B. Ibrahim. Menyususn Proposal Penelitian, Kisi-Kisi Praktis. Bangka Belitung: UBB PRESS. 2009;43. 